\title{
Competencies For Human Resource Development Practitioners
}

Barney Erasmus, University of South Africa, South Africa

Vadm Pieter Loedolff, University of South Africa, South Africa

Mr Filip Hammann, University of South Africa, South Africa

\begin{abstract}
This paper reports on research into the required competencies of human resource development practitioners $(H R D)$ in selected South African organizations. The research identified the level of importance and of satisfaction with the main competencies amongst HRD practitioners. Data was gathered from a random sample of business establishments. Data analysis indicated, firstly the importance of various competencies and the present satisfaction level, and secondly the differences between groups of some biographical variables in terms of the average level of importance and satisfaction of competencies. The results obtained have definite implications in the field of HRD and for education and training programmes offered by tertiary education institutions.
\end{abstract}

Keywords: human resource development, human resource managers, South Africa

\section{INTRODUCTION}

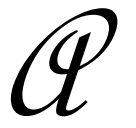

ccording to Coetzee (2007), South Africa is facing a critical skills gap, an ageing but highly skilled workforce, increasingly complex technology and rising consumer expectations from service providers. The same author suggests that the demand for quality education and training and competent and qualified human resource development (HRD) practitioners increases as people's needs to acquire the skills necessary for employment grow. The rapid pace of change in organisations in South Africa has already impacted significantly on the way in which knowledge and skills are transferred in organisations. Meyer (2007) argues that HRD has advanced so rapidly over the last ten years that traditional training is under threat. This has led to a situation in which an increasing number of companies regard HRD as a crucial factor to enhance competitiveness and overall performance. HRD should therefore not only be concerned with developing people but also play a key leadership role in supporting initiatives to enhance competitiveness and organisational performance and transformation (Fisher 1997; Noe 2008). Bhatnagar and Sharma (2005) support this argument in suggesting that HRD should be concerned with the management of employee learning in the long term, but keeping in mind the explicit corporate and business strategies. HRD is defined as "all the processes, systems, methods, procedures and programmes an organisation employs to develop its human resources in order to equip its employees to be able to contribute to organisational performance" (Meyer 2007:2) . Ulrich, Brockbank, Hohson, Sandholz and Younger (2008) argue that the human resource function should add value and make a meaningful contribution to employees and line managers inside the company, and to customers, communities, partners, and investors outside it. By the same token, it could be said that the HRD function should add value and contribute by equipping its employees with skills to help improve organisational performance.

The following questions arise: What competencies do HRD practitioners require to meet the demands of organisations? What should be the focus of tertiary education institutions to adequately prepare graduates to work in the field of HRD in South Africa?

This paper is structured as follows: The next section discusses the roles and competencies of HRD practitioners as identified in previous studies and in the literature. The research methodology is then explained, followed by a discussion of the results. Finally, conclusions are drawn. 


\section{ROLES AND COMPETENCIES OF HRD PRACTITIONERS}

\section{Roles of HRD practitioners}

According to Clardy (2008), the issue of roles and competencies has been a theoretical and research focus for a number of years in the HRD field. The primary reason for this is the obvious connection between roles and competency and performance. In one such study in 2004, the American Society for Training and Development (ASTD) identified the roles and competencies of training professionals in the so-called "competency model" (Noe 2008). The ASTD defined roles as "groupings of targeted competencies" (www.astd.org). They are not job titles but a set of skills needed to empower the individual. An individual's job may encompass one or more roles, similar to different "hats" we might have to "wear". At the top of the model, the ASTD study identified four unique roles for the HRD practitioner (Noe 2008), namely learning strategist, business partner, project manager and professional specialist. The learning strategist determines how HRD programmes can be best utilised to help meet the organisation's business strategy. The business partner uses business and industry knowledge to create training programmes that improve performance. The project manager plans, coordinates and monitors the effective delivery of training programmes that support the business. The professional specialist designs, develops, conducts and evaluates training and development programmes. These four roles are considered essential for an individual to be successful in the field of training and development.

\section{Competencies of HRD practitioners}

Coupled with the various roles are certain foundational competencies that HRD practitioners need. The ASTD study defines competencies as" clusters of skills, knowledge, abilities and behaviour for job success" (www.astd.org). The Society for Human Resources Management (SHRM) defines competencies as "attributes that are necessary for a person to possess in order to complete a particular job. These include knowledge, skills and abilities" (Google 2006). Foundational competencies refer to relevant behaviours for training and development professionals. These competencies include interpersonal, business and personal competencies. Table 1 reflects the required competencies that were identified in the ASTD study (www.astd.org; Noe 2008).

Table 1: Essential competencies for HRD practitioners as identified by the ASTD (USA)

\begin{tabular}{|c|c|c|}
\hline Business competencies & Interpersonal competencies & Personal competencies \\
\hline $\begin{array}{ll}\text { - } & \text { Analysing needs and proposing } \\
& \text { solutions } \\
\text { - } & \text { Applying business acumen } \\
\text { - } & \text { Driving results } \\
\text { - } & \text { Planning and implementing } \\
& \text { assignments } \\
\text { - } & \text { Thinking strategically }\end{array}$ & $\begin{array}{ll}\text { - } & \text { Building trust } \\
\text { - } & \text { Communicating effectively } \\
\text { - } & \text { Influencing stakeholders } \\
\text { - } & \text { Leveraging diversity } \\
\text { - } & \text { Networking and partnering }\end{array}$ & $\begin{array}{ll} & \text { Demonstrating adaptability } \\
\text { - } & \text { Modelling personal development }\end{array}$ \\
\hline
\end{tabular}

Source: www.astd.org

In an earlier study of HRD practitioners, McLagan (Valkeavaara 1998) identified four clusters of competencies. These were interpersonal competencies, business competencies, technical competencies (knowledge and delivery of traditional personnel and HRD management) and intellectual competencies. Table 2 shows these clusters together with the list of competencies of each cluster.

If one were to combine the findings of the two studies, one could conclude that HRD practitioners require the following combined clusters of competencies in order to be effective and be "business partners":

\footnotetext{
- $\quad$ business/management competencies

- $\quad$ interpersonal competencies

- $\quad$ personal competencies

- $\quad$ intellectual competencies

- technical competencies
} 
The two combined clusters of competencies provided a useful basis for empirical research into the competency requirements of South African HRD practitioners.

Table 2: Essential competencies for HRD practitioners as identified by McLagan

\begin{tabular}{|c|c|c|c|}
\hline Business competencies & Interpersonal competencies & Technical competencies & $\begin{array}{c}\text { Intellectual } \\
\text { competencies }\end{array}$ \\
\hline $\begin{array}{ll}\text { - } & \text { Business understanding } \\
\text { - } & \text { Cost-benefit analysis } \\
\text { - } & \text { Dkills } \\
\text { - } & \text { Industry understanding } \\
\text { - } & \text { Organisation behaviour } \\
\text { - } & \text { understanding } \\
\text { Organisation } \\
\text { development } \\
\text { understanding } \\
\text { - Project management } \\
\text { skills } \\
\text { Records management } \\
\text { skills }\end{array}$ & $\begin{array}{ll}\text { - } & \text { Coaching skills } \\
\text { - } & \text { Feedback skills } \\
\text { - } & \text { Group process skills } \\
\text { - } & \text { Negotiation skills } \\
\text { - } & \text { Presentation skills } \\
\text { - } & \text { Relationship building } \\
& \text { skills } \\
\text { - } & \text { Writing skills }\end{array}$ & $\begin{array}{ll}\text { - } & \text { Adult learning } \\
\text { - } & \text { Canderstanding } \\
& \text { understanding } \\
\text { - } & \text { Computer competence } \\
\text { - } & \text { Competency } \\
\text { - } & \text { identification skills } \\
\text { Electronic systems } \\
\text { skills } \\
\text { - } \text { Objectives preparation } \\
\text { - } \text { skills } \\
\text { Subject matter } \\
\text { - } \quad \text { Training and } \\
\text { development theories } \\
\text { - } \quad \text { Research skills } \\
\text { and techniques }\end{array}$ & $\begin{array}{ll}\text { - } & \text { Data reduction skills } \\
\text { - } & \text { Information search } \\
\text { - } & \text { skills } \\
\text { - } & \text { Intellectual versatility } \\
\text { - } & \text { Obdel building skills } \\
\text { - } & \text { Questioning skills } \\
\text { - } & \text { Self-knowledge } \\
\text { - } & \text { Visioning skills }\end{array}$ \\
\hline
\end{tabular}

Source: Valkeavaara (1998:179)

\section{AIM OF THE RESEARCH}

The aim of the research was to determine which of the above-mentioned competencies were applicable to HRD practitioners in South African organisations and to determine the level of importance of each competency and the level of satisfaction with the current knowledge and skills base in the organisation, as they apply to each main competency cluster.

\section{RESEARCH METHODOLOGY}

\section{Research population and sampling procedure}

The research population comprised all business establishments in the major business sectors of the South African economy. The sampling method used was stratified random sampling with proportional allocation. A random sample of business establishments was taken from each economic sector, and each business establishment included in the sample was contacted to identify the final sample elements (respondents) to complete the questionnaire. The questionnaire was then sent to the respondents, who were the human resource managers of the participating business establishments. A total sample size of 1320 business establishments was chosen to participate in the study.

\section{Data collection method and research instrument design}

The data were collected via the head offices of the relevant organisations by means of both a paper-based and a computer-aided self-administered questionnaires, which included single and multiple select and open-ended responses.

The main competency clusters referred to earlier were included in the questionnaire, namely business competencies, personal and interpersonal competencies, intellectual competencies and technical competencies. Because of the wide spectrum of technical competencies, it was decided to provide more specific information on this cluster of competencies in the questionnaire. Items 4 to 16 below reflect the technical competencies of the HRD practitioner): 
1 Business competencies (eg business acumen, budgeting)

$2 \quad$ Personal and interpersonal competencies (eg building trust, treating people fairly)

$3 \quad$ Intellectual competencies (eg intellectual versatility, visioning skills)

4 Strategic human resource development competencies (eg ensuring alignment with business strategies, developing long-range HRD strategies)

5 ETD-related legislation, strategies and policies (eg applying the requirements of the SAQA Act, developing learnership programmes)

$6 \quad$ Research skills (eg understanding research methodologies, compiling an ETD research report)

7 Learning theories and principles (eg applying various learning and principles, applying the principles of adult learning)

$8 \quad$ ETD needs analyses (eg conducting skills audits, analysing ETD needs)

$9 \quad$ Learning design and development (eg curriculum design, formulating learning outcomes)

10 Delivery of training (eg creating a learning environment, delivering electronic learning)

11 Guidance and learner support (eg advising and referring learners, developing and implementing learner support plans)

12 Skills development facilitation (eg developing a workplace skills plan, implementing skills development strategies)

13 Assessment and quality assurance (eg conducting assessment, managing a quality assurance system)

14 Evaluation of ETD (eg evaluating a course, measuring return on investment in training)

15 Occupational development (eg directing and guiding occupational development)

16 Administration of training (eg compiling an annual training plan, training records)

Each of the above-mentioned main competency clusters consists of a number of competencies. The respondents rated each competency in the questionnaire in terms of its importance and satisfaction. The questionnaire was structured in such a way that respondents had to indicate how important they regarded each competency as well as their current level of satisfaction with the competency in their organisation. The respondents had to respond on a five-point Likert scale, where a low rating (1) indicated that the respondents regarded the competency as not at all important for work application, whereas a high rating (5) indicated that they regarded the competency as very important for work application. Similarly, a low rating (1) indicated that the respondents were not at all satisfied with the competency and thus had a need for training in that competency, and a high rating (5) indicated that they were very satisfied with the competency and thus did not have a need for training in that competency.

\section{Fieldwork, response rate and limitation of the study}

The Bureau of Market Research of the University of South Africa administered and managed the fieldwork process. Despite the use of sampling strategies that support high response rates, only 47 business organisations ultimately participated in the research. This low response rate was possibly caused by the high intensity of business activities during the fieldwork process, as well as the length of the questionnaire as a result of the large number of competencies that had to be included in the questionnaire. The low response rate among business organisations was the main limitation of this study. Hence it was not possible to make comparisons across all economic sectors and to generalise the results to the whole population. The results of this study, however, provide a useful basis for further research.

\section{RESEARCH RESULTS AND DISCUSSION}

\section{Biographical information}

Respondents had to give information on biographical variables such as highest academic qualification, age, management level, present occupation, years in current position, main economic working sector, operating region and type of organisation.

The majority of participating organisations (64\%) were small with 50 or fewer employees) and operated in the regions of Gauteng, Western Cape, KwaZulu-Natal and Mpumalanga. Most of these organisations were private companies (68\%), parastatals (19\%) or government departments (6\%). 
The respondents worked mainly working in the economic sectors "Community, social education, health care and personal services" (36\%) and "Agriculture, hunting, forestry and fishing" (21\%). Regarding their highest qualifications, almost $20 \%$ of the respondents had a senior certificate or equivalent qualification; more than $10 \%$ had a national diploma or certificate, while almost $25 \%$ of the respondents had a postgraduate qualification.

Most of the respondents (43\%) were at least 44 years of age, and $47 \%$ of them had managerial positions at their business firms.

Most of the participating respondents worked as HRD or training managers (24\%), owners (15\%) or HRD directors $(10 \%)$ in their respective businesses. This enabled them to express valuable and objective views on the ETD issues affecting their business.

\section{Mean importance and satisfaction scores and rankings}

The mean importance and satisfaction scores for each of the 16 main competencies were calculated, and the main competencies were also ranked according to their mean importance and satisfaction scores. A ranking of 1 was the highest and a ranking of 16 the lowest. The results are depicted in table 3.

From table 3 it can be seen that the three main competency clusters, "business competencies", "personal/interpersonal competencies" and "intellectual competencies" obtained the highest mean importance scores as well as the highest mean satisfaction scores from the respondents.

Table 3: Mean importance/satisfaction scores and rankings for main competency

\begin{tabular}{|l|c|c|c|c|}
\hline \multicolumn{1}{|c|}{ Main competency } & $\begin{array}{c}\text { Mean } \\
\text { importance } \\
\text { score }\end{array}$ & $\begin{array}{c}\text { Mean } \\
\text { satisfaction } \\
\text { score }\end{array}$ & $\begin{array}{c}\text { Rank } \\
\text { (importance) }\end{array}$ & $\begin{array}{c}\text { Rank } \\
\text { (satisfaction) }\end{array}$ \\
\hline 1. Business competencies & 4.02 & 3.15 & 2 & 3 \\
\hline 2. Personal and interpersonal competencies & 4.13 & 3.27 & 1 & 1 \\
\hline 3. Intellectual competencies & 3.97 & 3.17 & 3 & 2 \\
\hline 4. Strategic human resource development competencies & 3.60 & 2.96 & 8 & 4 \\
\hline 5. ETD-related legislation, strategies and policies & 3.63 & 2.74 & 7 & 9 \\
\hline 6. Research skills & 3.53 & 2.62 & 11 & 11 \\
\hline 7. Learning theories and principles & 3.92 & 2.91 & 4 & 7 \\
\hline 8. ETD needs analyses & 3.73 & 2.92 & 6 & 6 \\
\hline 9. Learning design and development & 3.41 & 2.56 & 13 & 13 \\
\hline 10. Delivery of training & 3.53 & 2.76 & 10 & 8 \\
\hline 11. Guidance and learner support & 3.30 & 2.62 & 16 & 12 \\
\hline 12. Skills development facilitation & 3.58 & 2.70 & & 9 \\
\hline 13. Assessment and quality assurance & 3.31 & 2.54 & 15 & 10 \\
\hline 14. Evaluation of ETD & 3.51 & 2.55 & & 12 \\
\hline 15. Occupational development & 3.34 & 2.20 & & 14 \\
\hline 16. Administration of training & 3.83 & 2.95 & & 14 \\
\hline
\end{tabular}

The competencies were similarly analysed with respect to the mean importance/satisfaction scores they received from the respondents. The competencies which obtained the ten highest and ten lowest mean importance and satisfaction scores are shown in tables 4 and 5.

Most of the competencies which obtained the ten highest mean importance scores also received the ten highest mean satisfaction scores. These were: "Treating people fairly", "Communicating effectively", "Building trust", "Implementing decisions", etc (see tables 4 and 5). Similarly, most of the competencies that obtained the ten lowest mean importance scores also received the ten lowest mean satisfaction scores. The fact that the respondents gave these competencies both the highest importance and satisfaction ratings indicates that the current status of these competencies is intact and there is no immediate need for improvement or training. Although the competencies that received the lowest 
satisfaction and importance ratings from the respondents showed a need for training, this is not of vital importance for the respondents' jobs.

Table 4: Ten highest and ten lowest mean importance scores for subcompetencies

\begin{tabular}{|l|c|c|c|}
\hline \multicolumn{1}{|c|}{ Subcompetency } & Main competency & n & Mean importance score \\
\hline Treating people fairly & 2 & 46 & 4.61 \\
\hline Communicating effectively & 2 & 46 & 4.57 \\
\hline Building trust & 2 & 46 & 4.52 \\
\hline Implementing decisions & 1 & 46 & 4.50 \\
\hline Providing strategic direction & 1 & 44 & 4.45 \\
\hline Budgeting & 1 & 45 & 4.42 \\
\hline Relationship-building skills & 2 & 45 & 4.38 \\
\hline Ability to drive results & 1 & 46 & 4.33 \\
\hline Proposing solutions & 1 & 46 & 4.33 \\
\hline Analysing business issues and client needs & 1 & 46 & 4.28 \\
\hline & & & \\
\hline Developing assessment tasks & 13 & 41 & 3.27 \\
\hline Curriculum design & 9 & 42 & 3.26 \\
\hline Sequencing learning & 9 & 43 & 3.26 \\
\hline Analysing international trends in HRD & 4 & 42 & 3.24 \\
\hline Designing integrated assessment for a learning programme & 13 & 40 & 3.18 \\
\hline Moderating assessment & 13 & 41 & 3.17 \\
\hline Developing and implementing learner support plans & 11 & 41 & 3.15 \\
\hline Delivering electronic learning & 10 & 42 & 3.07 \\
\hline Developing online learning material & 9 & 41 & 2.98 \\
\hline Developing computer based learning material & 9 & 42 & 2.95 \\
\hline
\end{tabular}

Table 5: Ten highest and ten lowest mean satisfaction scores for subcompetencies

\begin{tabular}{|l|c|c|c|}
\hline \multicolumn{1}{|c|}{ Subcompetency } & Main competency & n & Mean satisfaction score \\
\hline Treating people fairly & 2 & 45 & 3.93 \\
\hline Budgeting & 1 & 44 & 3.64 \\
\hline Building trust & 2 & 45 & 3.58 \\
\hline Communicating effectively & 2 & 45 & 3.58 \\
\hline Relationship-building skills & 2 & 44 & 3.45 \\
\hline Information-searching skills & 3 & 42 & 3.40 \\
\hline Ability to drive results & 1 & 44 & \multicolumn{2}{c|}{3.36} \\
\hline Negotiating skills & 2 & 44 & 3.36 \\
\hline Implementing decisions & 1 & 45 & 3.36 \\
\hline Industry understanding & 1 & 45 & \multicolumn{2}{|c|}{} \\
\hline & & & 2.36 \\
\hline Curriculum design & 9 & 42 & 2.43 \\
\hline Developing assessment tasks & 13 & 40 & 2.42 \\
\hline Compiling an ETD research report & 6 & 43 & 2.40 \\
\hline Evaluating learning systems & 14 & 40 & 2.40 \\
\hline Moderating assessment & 13 & 40 & 2.39 \\
\hline Sequencing learning & 9 & 41 & 2.24 \\
\hline Developing computer-based learning material & 9 & 42 & 2.23 \\
\hline Directing occupational development & 15 & 39 & \\
\hline Engaging in occupational development & 15 & 39 & 2.21 \\
\hline Developing online learning material & 9 & 40 & \\
\hline
\end{tabular}




\section{Frequency tables and identifying critical main competency cluster}

Table 6 shows a special importance/satisfaction grid that was created to categorise the respondents into different sections according to their scores on both the importance and satisfaction of a main competency cluster. Scores were classified as low (1 or 2), average (3) or high (4 or 5). The respondents were categorised into either one of the sections A (low/low importance/satisfaction scores) to I (high/high importance/satisfaction scores), as described in table 6. The article focused on the sections $\mathrm{D}, \mathrm{G}$ and $\mathrm{H}$, since these were the areas of high importance but low satisfaction, and hence the critical sections.

As indicated in table 6, there was a corresponding action implementation for each section of the importance/satisfaction grid. This indicates how to deal with a main competency cluster after it has been categorised into a grid section. For example, if a high percentage of respondents rated a competency cluster as high/low on the importance/satisfaction scale, then the competency cluster was categorised into section $\mathrm{G}$ of the grid, with corresponding action implementation "Immediate action; priority area". This means that the main competency cluster was regarded as a priority area and immediate action would be needed to improve it.

A competency cluster is regarded as critical if it had a high total percentage of respondents in the sections $D, G$ and $\mathrm{H}$. The next step was to analyse each competency cluster to decide whether or not it could be identified as critical. The importance/satisfaction grid was used to set up frequency tables for each competency cluster to show the number of respondents in each of the grid sections A to I. By way of illustration, table 7 shows the frequency table for the competency, "strategic HRD.

Table 6: Importance/satisfaction grid with recommended action implementations

\begin{tabular}{|c|l|c|c|c|}
\hline \multicolumn{2}{|c|}{} & \multicolumn{2}{c|}{ Satisfaction } \\
\cline { 2 - 5 } & \multirow{2}{*}{ Low } & $\begin{array}{c}\text { A } \\
\text { Average }\end{array}$ & $\begin{array}{c}\text { High } \\
\text { Maintain standard; } \\
\text { no action required }\end{array}$ \\
\hline \multirow{2}{*}{$\begin{array}{l}\text { Ensure no further slippage } \\
\text { Average }\end{array}$} & $\begin{array}{c}\text { B } \\
\text { Restrict attention }\end{array}$ & $\begin{array}{c}\text { F } \\
\text { Maintain standard }\end{array}$ \\
\cline { 2 - 5 } & Target area for improvement & I & $\begin{array}{c}\text { I } \\
\text { Maintain standard; } \\
\text { improve where possible }\end{array}$ \\
\hline
\end{tabular}

Table 7: Number of respondents in each grid section for the main competency, strategic HRD

\begin{tabular}{|c|c|c|c|c|}
\hline & \multicolumn{3}{|c|}{ Satisfaction } \\
\hline & & Low & Average & High \\
\hline \multirow{3}{*}{ 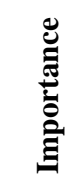 } & Low & 0 & 2 & 0 \\
\hline & Average & 3 & 8 & 1 \\
\hline & High & 9 & 12 & 7 \\
\hline
\end{tabular}

The following calculations were done on the basis of these frequency tables:

- the percentage of respondents in each grid section

- $\quad$ the grid section with the highest percentage of respondents

- $\quad$ the total percentage of respondents in critical sections $\mathrm{D}, \mathrm{G}$ and $\mathrm{H}$ 
The critical competencies identified through this process are reflected in table 8 .

Table 8: Identifying the critical main competencies

\begin{tabular}{|c|c|c|c|c|c|c|c|c|c|c|c|c|}
\hline \multirow{3}{*}{$\begin{array}{l}\text { Main competency } \\
\text { *1. Business } \\
\text { competencies }\end{array}$} & \multicolumn{9}{|c|}{ Percentage of respondents occurring in grid section } & \multirow{2}{*}{\multicolumn{2}{|c|}{$\begin{array}{l}\text { Maximum } \\
\text { grid section }\end{array}$}} & \multirow{3}{*}{$\begin{array}{c}\begin{array}{c}\text { Total } \\
\text { percentage } \\
(\mathbf{D}+\mathbf{G}+\mathbf{H})^{\mathrm{b}}\end{array} \\
61.4 \\
\end{array}$} \\
\hline & \multirow{2}{*}{$\begin{array}{c}\mathbf{A} \\
0.0\end{array}$} & \multirow{2}{*}{$\begin{array}{c}\mathbf{B} \\
0.0\end{array}$} & \multirow{2}{*}{$\frac{\mathbf{C}}{0.0}$} & \multirow{2}{*}{$\frac{\mathbf{D}}{0.0}$} & \multirow{2}{*}{$\frac{\mathbf{E}}{15.9}$} & \multirow{2}{*}{$\begin{array}{c}\mathbf{F} \\
2.3\end{array}$} & \multirow{2}{*}{$\begin{array}{l}\mathbf{G} \\
9.1\end{array}$} & \multirow{2}{*}{\begin{tabular}{c|}
$\mathbf{H}$ \\
52.3
\end{tabular}} & \multirow{2}{*}{$\frac{\mathbf{I}}{20.5}$} & & & \\
\hline & & & & & & & & & & $\mathrm{H}$ & 52.3 & \\
\hline $\begin{array}{l}\text { *2. Personal and } \\
\text { interpersonal } \\
\text { competencies }\end{array}$ & 2.3 & 2.3 & 0.0 & 2.3 & 6.8 & 2.3 & 9.1 & 47.7 & 27.3 & $\mathrm{H}$ & 47.7 & 59.1 \\
\hline $\begin{array}{l}\text { 3. Intellectual } \\
\text { competencies }\end{array}$ & 2.3 & 0.0 & 0.0 & 0.0 & 16.3 & 2.3 & 14.0 & 37.2 & 27.9 & $\mathrm{H}$ & 37.2 & 51.2 \\
\hline $\begin{array}{l}\text { *4. Strategic HRD } \\
\text { competencies }\end{array}$ & 0.0 & 4.8 & 0.0 & 7.1 & 19.1 & 2.4 & 21.4 & 28.6 & 16.7 & $\mathrm{H}$ & 28.6 & 57.1 \\
\hline $\begin{array}{l}\text { 5. ETD-related } \\
\text { legislation, strategies } \\
\text { and policies }\end{array}$ & 4.7 & 4.7 & 0.0 & 11.6 & 16.3 & 2.3 & 18.6 & 23.3 & 18.6 & $\mathrm{H}$ & 23.3 & 53.5 \\
\hline 6. Research skills & 18.6 & 0.0 & 0.0 & 14.0 & 14.0 & 2.3 & 16.3 & 23.3 & 11.6 & $\mathrm{H}$ & 23.3 & 53.5 \\
\hline $\begin{array}{l}* 7 . \text { Learning theories } \\
\text { and principles }\end{array}$ & 4.7 & 4.7 & 0.0 & 0.0 & 2.3 & 4.7 & 23.3 & 37.2 & 23.3 & $\mathrm{H}$ & 37.2 & 60.5 \\
\hline 8. ETD needs analyses & 7.0 & 2.3 & 0.0 & 9.3 & 11.6 & 4.7 & 14.0 & 25.6 & 25.6 & $H \& I$ & 25.6 & 48.8 \\
\hline $\begin{array}{l}\text { 9. Learning design and } \\
\text { development }\end{array}$ & 19.1 & 2.4 & 0.0 & 11.9 & 14.3 & 2.4 & 14.3 & 26.2 & 9.5 & $\mathrm{H}$ & 26.2 & 52.4 \\
\hline $\begin{array}{l}* 10 . \text { Delivery of } \\
\text { training }\end{array}$ & 12.2 & 0.0 & 0.0 & 14.6 & 12.2 & 2.4 & 9.8 & 29.3 & 19.5 & $\mathrm{H}$ & 29.3 & 53.7 \\
\hline $\begin{array}{l}\text { 11. Guidance and } \\
\text { learner support }\end{array}$ & 15.0 & 2.5 & 2.5 & 10.0 & 15.0 & 2.5 & 15.0 & 17.5 & 20.0 & I & 20.0 & 42.5 \\
\hline $\begin{array}{l}\text { 12. Skills } \\
\text { development } \\
\text { facilitation }\end{array}$ & 9.8 & 2.4 & 0.0 & 9.8 & 14.6 & 2.4 & 22.0 & 12.2 & 26.8 & I & 26.8 & 43.9 \\
\hline $\begin{array}{l}\text { 13. Assessment and } \\
\text { quality assurance }\end{array}$ & 22.5 & 5.0 & 0.0 & 2.5 & 15.0 & 2.5 & 22.5 & 20.0 & 10.0 & G & 22.5 & 45.0 \\
\hline 14. Evaluation of ETD & 19.5 & 4.9 & 2.4 & 0.0 & 14.6 & 2.4 & 24.4 & 24.4 & 7.3 & $\mathrm{H}$ & 24.4 & 48.8 \\
\hline $\begin{array}{l}\text { *15. Occupational } \\
\text { development }\end{array}$ & 17.5 & 2.5 & 0.0 & 10.0 & 12.5 & 2.5 & 30.0 & 25.0 & 0.0 & G & 30.0 & 65.0 \\
\hline $\begin{array}{l}\text { 16. Administration of } \\
\text { training }\end{array}$ & 7.0 & 2.3 & 2.3 & 2.3 & 2.3 & 2.3 & 23.3 & 25.6 & 32.6 & I & 32.6 & 51.2 \\
\hline
\end{tabular}

It was found that competency 15 (occupational development) had the highest percentage of 65\%, competency 1 (business competencies) was next with a percentage of $61.4 \%$, followed by competency 7 (learning theories and principles) with $60.5 \%, \mathrm{HRD}$ ) with $57.1 \%$ and number 10 (delivery of training), with a percentage of $53.7 \%$. These competencies were considered the most critical in terms of their total percentage of respondents in sections $\mathrm{D}, \mathrm{G}$ and $\mathrm{H}$. The grid sections $\mathrm{G}, \mathrm{H}$ and I contained the highest percentage of respondents.

Figure 1 is a graphical representation of the total percentage of respondents in critical grid sections $\mathrm{D}, \mathrm{G}$ and $\mathrm{H}$, for each of the 16 main competencies. 
Figure 1: Total percentage of respondents in critical sections $D, G$ and $H$ per main competency

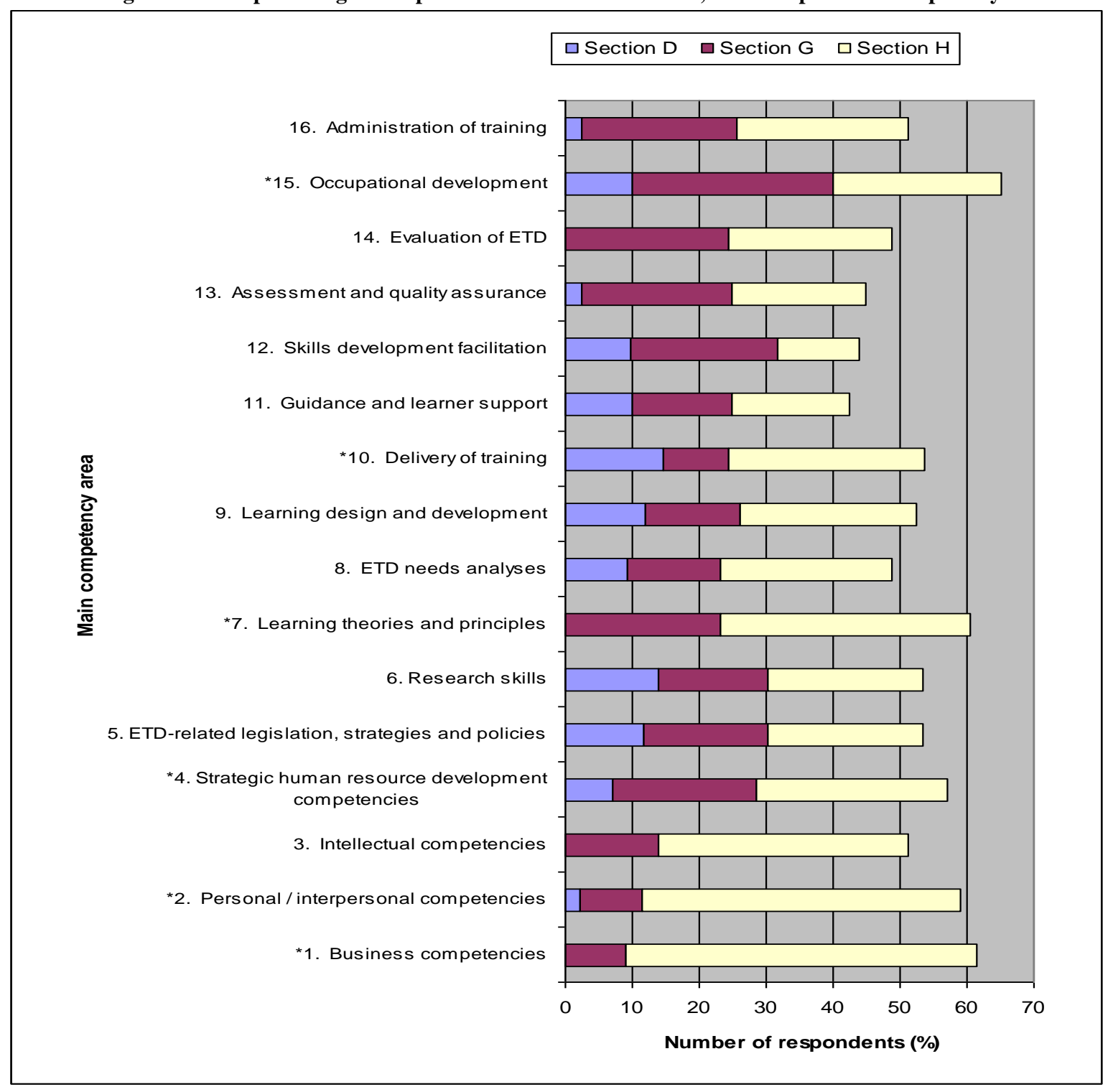

\section{Further analysis of the critical competencies}

After identifying the critical competencies, further analysis was done by means of descriptive and visual statistics. The purpose of this activity was to gain further insight into the critical competencies by checking if the majority of its subcompetencies were also critical, as one would have expected.

\section{Cross-tabulations}

Cross-tabulation tables were constructed for the subcompetencies in each critical main competency. For example, table 9 shows the result for the specific subcompetency, analysing international trends in HRD, in the main competency, strategic HRD. 
Table 9: Cross-tabulation of the subcompetency: analysing international trends in HRD

\begin{tabular}{|c|c|c|c|c|c|c|c|}
\hline \multicolumn{2}{|c}{} & \multicolumn{7}{c|}{ Satisfaction score } & \multirow{2}{*}{ Total } \\
\cline { 2 - 8 } & & $\mathbf{1}$ & $\mathbf{2}$ & $\mathbf{3}$ & $\mathbf{4}$ & $\mathbf{5}$ & $12.2 \%$ \\
\hline \multirow{3}{*}{$\begin{array}{c}\text { Importance } \\
\text { score }\end{array}$} & $\mathbf{1}$ & $7.3 \%$ & & $4.9 \%$ & & & $17.1 \%$ \\
\cline { 2 - 8 } & $\mathbf{2}$ & $4.9 \%$ & $7.3 \%$ & $2.4 \%$ & & $2.4 \%$ & $22.0 \%$ \\
\cline { 2 - 8 } & $\mathbf{3}$ & & $2.4 \%$ & $19.5 \%$ & & & $31.7 \%$ \\
\cline { 2 - 8 } & $\mathbf{4}$ & & $4.9 \%$ & $17.1 \%$ & $7.3 \%$ & $2.4 \%$ & $17.1 \%$ \\
\hline Total & $\mathbf{5}$ & $7.3 \%$ & & $4.9 \%$ & $2.4 \%$ & $2.4 \%$ & $100 \%$ \\
\hline
\end{tabular}

In general it was found that only the following subcompetencies had less than $30 \%$ of respondents occurring in critical sections $\mathrm{D}, \mathrm{G}$ and $\mathrm{H}$ :

- $\quad$ career planning and talent management (main competency cluster, business/management competencies)

- $\quad$ budgeting (main competency area, business/management competencies)

- $\quad$ treating people fairly (main competency area, personal and interpersonal competencies)

- $\quad$ delivering electronic learning (main competency area, delivery of training)

From these results it can be concluded that the specific competencies in each critical main competency cluster were also critical, which was to be expected, and one can therefore focus on these specific competencies to improve a competency cluster.

\section{Analysis of variance}

Analysis of variance tests was used to determine whether significant differences existed between the groups of biographical variables in terms of the mean importance and satisfaction scores for the main competencies. In order to obtain large enough sample sizes for the test provide sensible results, each biographical variable was divided into three groups of respondents. Table 10 shows the descriptions of each of these groups. An analysis of variance test was performed for each biographical variable as the independent variable to determine whether the average importance and satisfaction scores of the three groups for each main competency were significantly different.

Table 10: Biographical variable groups

\begin{tabular}{|c|c|c|c|}
\hline Biographical variable & Group A & Group B & Group C \\
\hline Age & 20-39 years & $40-49$ years & 50 years and older \\
\hline Present occupation & $\begin{array}{l}\text { - HRD or training manager } \\
\text { - HRD director } \\
\text { - HR director/manager }\end{array}$ & $\begin{array}{l}\text { - Administrator } \\
\text { - Skills development facilitator } \\
\text { - Owner/manager }\end{array}$ & $\begin{array}{l}\text { - Project manager } \\
\text { - Managing director } \\
\text { - Financial director/ } \\
\text { manager } \\
\text { - Researcher } \\
\text { - Other occupations }\end{array}$ \\
\hline $\begin{array}{l}\text { Main economic } \\
\text { working sector }\end{array}$ & $\begin{array}{l}\text { Agriculture, hunting, } \\
\text { forestry and fishing }\end{array}$ & $\begin{array}{l}\text { - Wholesale and retail trade; repair of } \\
\text { motor vehicles, motor cycles, personal } \\
\text { and household goods, hotels and } \\
\text { restaurants } \\
\text { - Manufacturing } \\
\text { - Financial institutions, insurance, real } \\
\text { estate and business } \\
\text { - Transport, storage and } \\
\text { communication } \\
\text { - Mining and quarrying } \\
\text { - Construction }\end{array}$ & $\begin{array}{l}\text { Community, social } \\
\text { education, health-care and } \\
\text { personal services }\end{array}$ \\
\hline Type of organisation & Private company & Parastatal & $\begin{array}{l}\text { - Government departments } \\
\text { - Other types of } \\
\text { organisations }\end{array}$ \\
\hline
\end{tabular}


The biographical variables for which there were differences between groups at the $1 \%$ level of significance $(\mathrm{p}<$ $0.01)$ and the $5 \%$ level of significance $(\mathrm{p}<0.05)$ are shown in table 11 for the mean important scores, and table 12 for the mean satisfaction scores. In cases where there were unequal variances between the groups, the Welch test procedure was applied as a more robust alternative to obtain more accurate results.

Table 11: Summary of analysis of variance results: significant differences between biographical variable groups in terms of mean important scores for main competency areas

\begin{tabular}{|c|c|c|c|c|}
\hline $\begin{array}{l}\text { Biographical variable } \\
\text { (independent variable) }\end{array}$ & $\begin{array}{c}\text { Main competency cluster } \\
\text { (dependent variable) }\end{array}$ & $\mathbf{F}$ & $\mathbf{p}$ & $\begin{array}{c}\text { Groups } \\
\text { that differ }^{\text {a }}\end{array}$ \\
\hline \multirow{7}{*}{ Age } & 1. Business competencies & 3.414 & $0.043^{*}$ & $\mathrm{~A}-\mathrm{C}$ \\
\hline & 2. Personal and interpersonal competencies & 4.088 & $0.024 *$ & $\mathrm{~A}-\mathrm{C}$ \\
\hline & 3. Strategic HRD competencies & 5.062 & $0.011 *$ & $\mathrm{~A}-\mathrm{C}$ \\
\hline & 4. Intellectual competencies & 9.945 & $0.000 * *$ & $\mathrm{~A}-\mathrm{C}$ \\
\hline & 8. ETD needs analyses ${ }^{\wedge}$ & 9.202 & $0.001 * *$ & $\begin{array}{l}\text { A - B } \\
\text { A - C }\end{array}$ \\
\hline & 10. Delivery of training & 3.415 & $0.044 *$ & $\mathrm{~A}-\mathrm{C}$ \\
\hline & 16. Administration of training ${ }^{\wedge}$ & 6.764 & $0.006^{* *}$ & $\mathrm{~A}-\mathrm{C}$ \\
\hline \multirow{11}{*}{$\begin{array}{l}\text { Main economic working } \\
\text { sector }\end{array}$} & 2. Personal and interpersonal competencies & 5.633 & $0.007 * *$ & $\mathrm{C}-\mathrm{B}$ \\
\hline & 3. Strategic HRD competencies & 4.611 & $0.016^{*}$ & $\mathrm{C}-\mathrm{B}$ \\
\hline & 4. Intellectual competencies & 5.071 & $0.011 *$ & $\mathrm{C}-\mathrm{B}$ \\
\hline & 7. Learning theories and principles ${ }^{\wedge}$ & 5.713 & $0.009 * *$ & $\mathrm{C}-\mathrm{B}$ \\
\hline & 8. ETD needs analyses & 4.928 & $0.012 *$ & $\mathrm{C}-\mathrm{B}$ \\
\hline & 9. Learning design and development & 9.174 & $0.001 * *$ & $\mathrm{C}-\mathrm{B}$ \\
\hline & 10. Delivery of training & 5.807 & $0.006 * *$ & $\mathrm{C}-\mathrm{B}$ \\
\hline & 11. Guidance and learner support & 5.627 & $0.007 * *$ & $\mathrm{C}-\mathrm{B}$ \\
\hline & 12. Skills development facilitation & 3.905 & $0.028 *$ & $\mathrm{C}-\mathrm{B}$ \\
\hline & 14. Evaluation of ETD & 6.488 & $0.004 * *$ & $\mathrm{C}-\mathrm{B}$ \\
\hline & 16. Administration of training $\wedge$ & 6.225 & $0.006^{* *}$ & $\mathrm{C}-\mathrm{B}$ \\
\hline \multirow{9}{*}{ Type of organisation } & 2. Personal and interpersonal competencies & 6.339 & $0.004 * *$ & $\mathrm{~B}-\mathrm{A}$ \\
\hline & 3. Strategic HRD competencies & 5.442 & $0.008 * *$ & $\mathrm{~B}-\mathrm{A}$ \\
\hline & 4. Intellectual competencies & 4.615 & $0.016^{*}$ & $\mathrm{C}-\mathrm{A}$ \\
\hline & $\begin{array}{l}\text { 5. ETD-related legislation, strategies and } \\
\text { policies }\end{array}$ & 3.432 & $0.042 *$ & $\mathrm{C}-\mathrm{A}$ \\
\hline & 7. Learning theories and principles & 5.049 & $0.011^{*}$ & $\mathrm{~B}-\mathrm{A}$ \\
\hline & 8. ETD needs analyses & 5.921 & $0.006 * *$ & $\mathrm{C}-\mathrm{A}$ \\
\hline & 9. Learning design and development & 6.880 & $0.003 * *$ & $\mathrm{C}-\mathrm{A}$ \\
\hline & 11. Guidance and learner support & 4.123 & $0.024^{*}$ & $\mathrm{~B}-\mathrm{A}$ \\
\hline & 16. Administration of training & 3.975 & $0.026^{*}$ & $\mathrm{~B}-\mathrm{A}$ \\
\hline
\end{tabular}

Table 12: Summary of analysis of variance results: significant differences between biographical variable groups in terms of mean satisfaction scores for main competency areas

\begin{tabular}{|c|c|c|c|c|}
\hline $\begin{array}{c}\text { Biographical variable } \\
\text { (independent variable) }\end{array}$ & $\begin{array}{c}\text { Main competency cluster } \\
\text { (dependent variable) }\end{array}$ & $\mathbf{F}$ & $\mathbf{p}$ & $\begin{array}{c}\text { Groups } \\
\text { that differ }\end{array}$ \\
\hline Present occupation & 11. Guidance and learner support & 4.157 & $0.025^{*}$ & $\mathrm{~A}-\mathrm{C}$ \\
\hline \multirow{2}{*}{$\begin{array}{l}\text { Main economic } \\
\text { working sector }\end{array}$} & 6. Research skills & 3.847 & $0.030^{*}$ & $\mathrm{C}-\mathrm{A}$ \\
\hline & 11. Guidance and learner support & 3.677 & $0.035^{*}$ & $\mathrm{C}-\mathrm{A}$ \\
\hline \multirow[t]{3}{*}{ Type of organisation } & 5. ETD-related legislation, strategies and policies & 4.517 & $0.017^{*}$ & $\mathrm{C}-\mathrm{B}$ \\
\hline & 11. Guidance and learner support & 4.123 & $0.024 *$ & $\mathrm{~B}-\mathrm{A}$ \\
\hline & 15. Occupational development & 3.617 & $0.037 *$ & $\mathrm{~A}-\mathrm{B}$ \\
\hline
\end{tabular}


Significant differences between group average importance scores were found for the biographical variables of age, main economic working sector and type of organisation.

The respondents aged between 20 and 39 years in comparison with the older respondents (50 and older) regarded the main competencies, personal and interpersonal competencies, strategic HRD competencies, intellectual competencies, ETD needs analyses and administration of training as more important, while those respondents working in main economic sector $\mathrm{C}$, compared with the respondents in main economic sector $\mathrm{B}$, regarded these main competencies as more important. Also, parastatals, comparison with private companies, felt that personal and interpersonal competencies, strategic HRD competencies and administration of training were more important. while government departments, compared with private companies, regarded strategic HRD and ETD needs analyses as more important.

Significant differences between group average satisfaction scores were found for the biographical variables, present occupation, main economic working sector and type of organisation.

The respondents in occupation $\mathrm{C}$ are more in need of training in the main competencies guidance and learner support than respondents in occupation A, while respondents working in the main economic sector A are more in need of training in the main competencies research skills and guidance and learner support than respondents working in main economic sector $\mathrm{C}$.

Furthermore, parastatals are more in need of training in ETD-related legislation, strategies and policies than government departments; private companies are more in need of training in guidance and learner support than parastatals; and parastatals are more in need of training in occupational development than private companies.

\section{Histograms}

For each critical main competency, a histogram was drawn to indicate the frequency of the occurrence of the importance/satisfaction scores, as rated on a scale of 1 to 5. Figure 2 shows the result for the critical main competency, learning theories and principles. The histogram shows that a large number of respondents gave a high importance score of 4 or 5, but far fewer respondents had a high satisfaction score. All of the critical main competencies showed the same result, where a critical main competency received high importance scores from most of the respondents, but ad high satisfaction scores from very few of the respondents. This indicates a tendency among the respondents to rate the critical main competencies as high on the importance scale, but low on the satisfaction scale.

Figure 2: Histogram of scores for the main competency, learning theories and principles

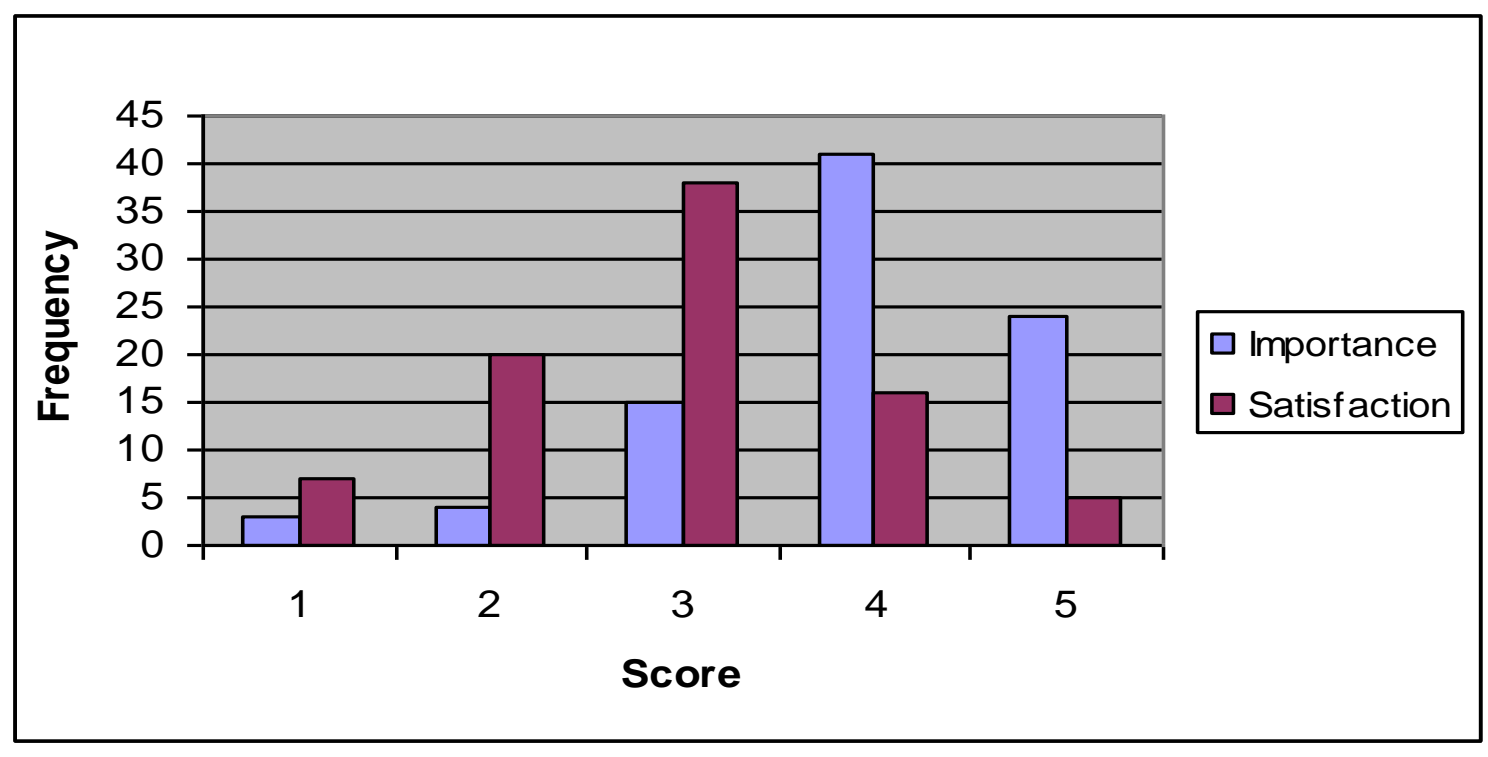




\section{DISCUSSION}

The literature study was aimed at identifying the various main competency clusters required by HRD practitioners. These competencies were used as the point of departure for the empirical study, which attempted to determine the level of importance of each main competency as well as the present level of satisfaction among a sample of South African-based business organisations.

The results clearly indicated the importance of the various main competencies. The study confirmed that HRD practitioners require five sets of competencies, namely business/management competencies, interpersonal competencies, personal competencies, intellectual competencies and a variety of technical competencies.

The results also highlighted the relative importance of each of the competencies as well as the present satisfaction level among the business organisations that participated in the study. The statistical analysis identified those competencies that are critical, that is, those competencies that are the most important and show the least amount of satisfaction among the participating business organisations. These were business competencies, personal and interpersonal competencies, strategic HRD competencies, learning theories and principles, delivery of training and occupational development.

The three main competency clusters of business competencies, personal and interpersonal competencies and intellectual competencies were the most important and also rated as the most satisfying among respondents, which indicates that there is not an immediate need for employees to be trained in these three main competency clusters.

It is well established that for HRD practitioners to be effective, they not only have to understand the business in which they render a service, but they should also be exposed to the basic business and management competencies to ensure the success of the business, for example, budgeting and financial management skills. The importance of this aspect of the work of HRD practitioners is evident in the results of the research. The results also indicate the importance to the HRD practitioner of a variety of technical competencies. The HRD practitioner is no longer only a trainer - he or she needs to be multiskilled in a variety of competencies in order to play a meaningful role in the organisation. Also, certain main competency clusters, such as personal and interpersonal competencies, strategic HRD competencies, intellectual competencies, ETD needs analyses and administration of training, are more important in organisations in the opinion of younger employees (between 20 and 39 years of age) than older employees (50 years and older).

The cross-tabulation of the results provided further insight in terms of the satisfaction level among participants of the specific competencies in each main competency cluster and the fact that there is a need to focus on these competencies in education and training in order to improve on the main competency clusters as a whole.

The results of this study have definite implications for teaching and learning in the field of HRD. There is not only greater awareness of the important main competency clusters, but also of the specific competencies that need to be addressed in the education and training programmes offered by tertiary education institutions.

\section{CONCLUSION}

This study focused primarily on the competencies of HRD practitioners. The study has merit because for the first time in a study of this kind, the focus has been on identifying the competencies instead of the knowledge and skills requirements of HRD practitioners. The critical main competency clusters identified can be seen as the most relevant, and in most need of improvement. The measurement of the levels of importance and satisfaction of certain main competency clusters enabled the researchers to identify the most critical main competency areas. The results indicated that the most critical HRD competencies are occupational development, business competencies, learning theories and principles, personal and interpersonal competencies, strategic HRD and delivery of training. These main competency clusters are also a sound reflection of the needs of the HRD profession. On the basis of the results of the study, the following recommendations are made: 
- $\quad$ The education and training provided by companies for their personnel should focus on these competencies to effectively improve their skills.

- The study of these main competency clusters should be included in tertiary education programmes dealing with HRD, and will help to keep abreast of the rapid pace of change in the field of HRD.

- The main competency of delivery of training merits special mention. By focusing on improvement of this main competency, much could be done to revolutionise the way in which training and services are provided.

- Education and training-related legislation needs to focus on these critical competencies in order to influence the HRD sector in the best possible way. Tertiary education institutions should include these main competency clusters in their HRD-related courses and programmes to equip HRD practitioners with the most relevant competencies and skills.

\section{REFERENCES}

1. Bhatnagar, J \& Sharma, A. 2005. The Indian perspective of strategic roles and organizational learning capability. International Journal of Human Resource Management 16(9):1711-1739.

2. Clardy, A. 2008. Human resource development and the resource-based model of core competencies: methods for diagnosis and assessment. Human Resource Development Review 7:387-388.

3. Coetzee, M (ed). 2007. Practising, education, training and development in South African organisations. Cape Town: Juta:1-2

4. Fisher, C. 2005. HRD attitudes: the roles and ethical stances of human resource developers. Human Resource Development International 8(2):1.

5. Goodge, P. 2006. Competencies for the New HR. Competency and Emotional Intelligence 13(4):34-37.

6. Meyer M. 2007. Managing human resource development: an outcomes-based approach.

7. Durban: LexisNexis:2-5.

8. Noe, RA. 2008. Employee training and development. New York: McGrawHill:2.

9. Ulrich, D, Brockbank, W, Hohnson, D, Sandholtz, K \& Younger, J. 2008. HR competencies: mastery at the intersection of people and business. Michigan: Society for Human Resource Management:1.

10. Valkeavaara, T. 1998. Human resource development roles and competencies in five European countries. International Journal of Training and Development 2(3):177-179.

11. www.astd.org/content/research/competency/AreasofExpertise.htm. Accessed: 24 July 2009. 